This item was submitted to Loughborough's Research Repository by the author.

Items in Figshare are protected by copyright, with all rights reserved, unless otherwise indicated.

\title{
Direct measurement of piston friction of internal-combustion engines using the floating-liner principle
}

PLEASE CITE THE PUBLISHED VERSION

http://dx.doi.org/10.1177/0954407013511795

\section{PUBLISHER}

Sage Publications / @ IMechE

VERSION

VoR (Version of Record)

\section{PUBLISHER STATEMENT}

This work is made available according to the conditions of the Creative Commons Attribution 3.0 Unported (CC BY 3.0) licence. Full details of this licence are available at: http://creativecommons.org/licenses/by/3.0/

\section{LICENCE}

CC BY 3.0

\section{REPOSITORY RECORD}

Gore, Michael, Michael Theaker, S.J. Howell-Smith, Homer Rahnejat, and P.D. King. 2019. "Direct Measurement of Piston Friction of Internal-combustion Engines Using the Floating-liner Principle". figshare. https://hdl.handle.net/2134/17751. 


\title{
Direct measurement of piston friction of internal-combustion engines using the floating-liner principle
}

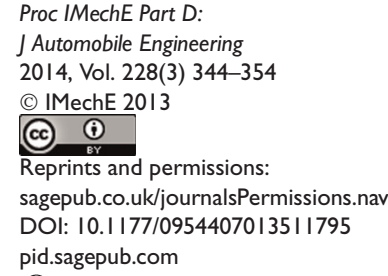
DOI: 10.1 I77/09544070I35। I795 pid.sagepub.com

@SAGE

\author{
Michael Gore', Michael Theaker', Sebastian Howell-Smith², \\ Homer Rahnejat' and Paul D King'
}

\begin{abstract}
Piston-cylinder interactions account for a significant portion of frictional losses in an internal-combustion engine. This is mainly as the result of significant changes in the operating conditions (the load, the speed and the temperature) as well as the contact geometry and the encountered topography during a typical engine cycle. These changes alter the regime of lubrication which underlies the mechanisms of friction generation. The multi-variate interactive nature of the problem requires quite complex analyses which do not fully replicate the actual in-situ conditions. Therefore, there is a need for direct measurement of cyclic friction under controlled conditions. The paper describes the use of a novel floating-liner arrangement which is capable of direct measurement of friction, its transitory mechanisms, as well as determination of the regime of lubrication.
\end{abstract}

\section{Keywords}

Internal-combustion engine, friction, piston-cylinder system, floating liner

Date received: I March 2013; accepted: 9 October 2013

\section{Introduction}

Road transport is now inexorably linked to modern living. It is also one of the underpinnings of economic development and its sustenance. However, nearly all vehicles rely on fossil fuels as the means of propulsion. The scarcity of these resources and the adverse effects of the ensuing emission products are gradually pressuring engine designers and developers to adhere to improving the fuel efficiency and to reducing the emissions. Alternative sources of propulsion power as well as energy recovery are also being actively pursued. Irrespective of the means of propulsion chosen, parasitic losses, mostly friction, will be regarded as a nemesis and an important energy sink.

Friction accounts for $15-20 \%$ of all the internalcombustion engine losses. ${ }^{1}$ The share of frictional losses increases at idling and low speeds such as those in crawling congested traffic. This is the case in the urban areas and even increasingly on major trunk routes. Therefore, a reduction in friction is seen as essential in the development of new engines, which is driven by a number of key concerns: the fuel efficiency, the emission levels, the noise, vibration and harshness refinement and the cost. It is also noteworthy that the transport sector accounts for $14 \%$ of the worldwide greenhouse gas emissions. ${ }^{2}$

The piston system accounts for $40-50 \%$ of all the parasitic losses; these include friction as well as the heat generated in load-bearing conjunctions, which is conducted away through the bounding solid surfaces. ${ }^{3}$ Furthermore, this is the key subsystem where the interrelationship between thermodynamics, inertial dynamics, elastodynamics, tribology and emissions becomes the most pronounced; this is a relationship which often poses paradoxical design issues. For instance, very tight sealing functionality of the compression ring can often be a concern because of its potential adverse effect on friction.

There have been considerable predictive analyses from the multitude of piston-bore conjunctions,

\footnotetext{
'Wolfson School of Mechanical and Manufacturing Engineering, Loughborough University, Loughborough, Leicestershire, UK

${ }^{2}$ Capricorn Automotive Ltd, Basingstoke, Hampshire, UK
}

\section{Corresponding author:}

Homer Rahnejat, Wolfson School of Mechanical and Manufacturing Engineering, Loughborough University, Ashby Road, Loughborough, Leicestershire LEI I 3TU, UK.

Email: H.Rahnejat@lboro.ac.uk 
including the top compression ring, ${ }^{4-6}$ the oil control ring and the piston skirt. ${ }^{3,7-9}$ The analyses have often been confined to one of these conjunctions without regard to their interconnected behaviour. Additionally, the complexity and multiplicity of interactions have often necessitated the exclusion of certain phenomena. For example, the combination of the elastodynamics of the compression ring and the transient hydrodynamics has been rarely reported. Baker et al. ${ }^{10}$ showed that, while the ring modal behaviour caters for its sealing function, its longer settling time guards against complete conformance to an idealised right circular cylinder, which would otherwise result in excessive friction. With thin films of the order of a few micrometres at best, particularly at piston reversals, boundary interactions account for a significant portion of cyclic frictional losses. Many studies have included the effect of surface topography, excluding ring modal behaviour, in predicting friction. ${ }^{4-11,12}$ Others have also included the effect of surface treatments, such as coatings ${ }^{13}$ or cross-hatch honing of cylinder liners ${ }^{14}$ or inclusion of a laser-textured liner surface at piston reversal at the top dead centre (TDC) in piston skirt lubrication. ${ }^{15}$

Bore out-of-roundness is another key parameter, which affects the conjunctional geometry, and thus friction and the ring-sealing function, as well as the oil loss, potential blow-by and lubricant degradation. ${ }^{16,17}$ Furthermore, the process of wear changes the geometry of the contiguous solids as well as the surface topography, which affect the tribological conditions in the ring-bore contact. ${ }^{13,17-19}$

Generated heat due to combustion and to a lesser extent that generated in the contact conjunction itself alters the viscosity of the lubricant, as well as causing thermoelastic distortion of the piston skirt. These significantly affect the tribological conditions and require thermoelastohydrodynamic analysis. Morris et al. ${ }^{6}$ demonstrated a considerably reduced film thickness in the compression ring-bore contact with generated heat, and Littlefair et al., ${ }^{20}$ McClure $^{21}$ and $\mathrm{Bai}^{22}$ took into account the thermoelastic distortion of the piston skirt in their piston skirt lubrication studies.
It is, therefore, clear that any realistic analysis would necessitate inclusion of a plethora of interactive physical phenomena in order to replicate realistic engine running conditions closely. Although good agreement has been reported between predictions and controlled laboratory-based motorised engine tests, such as the predictions by Akalin and $\mathrm{Newaz}^{23}$ and Mishra et al. ${ }^{5}$ with the experimental work of Furuhama and Sasaki, ${ }^{24}$ still direct measurement of friction under in-situ fired engine conditions is essential. The work by Furuhama and Sasaki ${ }^{24}$ was a culmination of the original work by Furuham and Takiguchi, ${ }^{25}$ measuring the forces transmitted to a floating liner whose motion was restricted through a set of intervening piezoelectric transducers. The infinitesimal (of the order of a few micrometres) motion of the liner generates inertial force responses proportional to the resistive force, which is friction, having taken into account the variations in the gas pressure loading. This principle was used by other researchers such as Yoshida et al. ${ }^{26}$ in the measurement of friction for different surface treatments.

This paper presents an instrumented floating liner, incorporated within the cylinder block of a highperformance single-cylinder motocross motorcycle engine, the piston ring pack of which consists of a compression ring and an oil control ring. The engine employs a short compliant partial piston skirt on the thrust-anti-thrust plane. The piston traverse speed range is $0-35 \mathrm{~m} / \mathrm{s}$ (with a maximum engine speed of $10,000 \mathrm{r} / \mathrm{min}$ ) with maximum side loads of the order of $5 \mathrm{kN}$. This combination more than envelops the expected performance of any original equipment manufacturer (OEM) engine and matches almost all those used by the racing fraternity.

\section{Principles of operation of a floating liner}

The principle of a floating-liner device is to suspend the liner in such a way that a number of piezoelectric load cells intervene at any point of contact between the liner and any rigidly mounted components. ${ }^{27}$ Figure 1 illustrates the assembly which contains the floating liner,

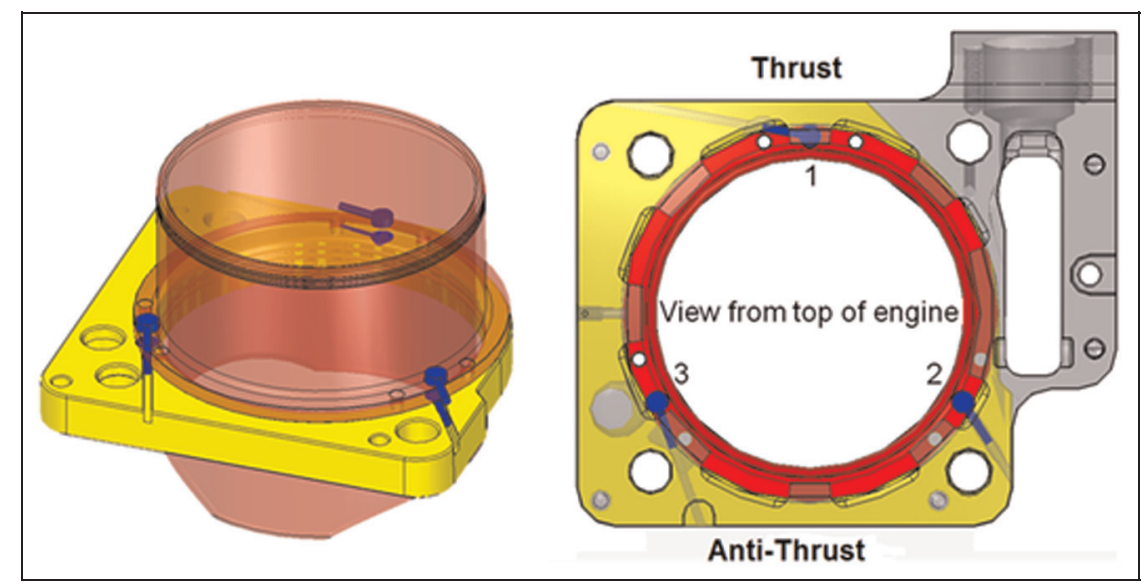

Figure I. The floating liner. 
held within a fixture through three piezoelectric load cells positioned at $120^{\circ}$ spacing. As the piston assembly reciprocates, the applied forces on to the liner cause infinitesimal movements of the liner relative to its rigidly held fixture within the engine cylinder. These forces are measured by the intervening load cells as

$$
\begin{aligned}
\sum f & =P-F \\
& =R-P_{r} \\
& =m a_{l}
\end{aligned}
$$

The load cells are preloaded at $P_{r}$ while in situ and at rest, including the weight of the liner itself. This represents the static equilibrium position, where the preload value is obtained and recorded prior to any testing. The infinitesimal movement of the liner is such that the load cells remain perpetually in compression. In effect, the dynamic changes in the applied load to the load cells is obtained from the difference between their instantaneous output value $R$ and the preload value (static equilibrium position) $P_{r}$ (i.e. $R-P_{r}$ ). This equates to the net applied force $\sum f$ on the load cells which must equate to the inertial force due to the motion of the liner (right-hand side of equation (1)). This net force is also the same as the forces applied to the liner itself, which are the pressure loading $P$ to the top rim of the liner and the opposing friction $F$ depending on the sense of motion of the liner relative to its stationary holding fixture. Friction can thus be obtained. Equation (1) assumes pure axial inertial dynamics of the piston, in which the combined load cell readings equal $R$. In reality, the liner pivots about its midriff brace, in contact with the holding fixture. Thus, the differences in individual readings of the load cells provide the embodied side force and the sense of any small tilt of the liner. These are taken away from the load cell readings to obtain the correct value of $R$ in the vertical axial direction. Provisions are made to minimise any tilt of the liner as it is in most part unconstrained. Design analysis is required to ensure that resonant frequencies or excess deflections are not reached under any intended engine operating condition. For this purpose, finite element modal analysis of the floating liner, constrained within its holding fixture, is carried out to obtain various mode shapes of the in-situ liner, subjected to a range of mechanical applied loads and thermal loading. The analysis is fairly routine, but quite detailed in the design of pistons and liners. It has been described for the floating liner by Gore et al. ${ }^{27}$ and for the piston by Littlefair et al. ${ }^{28}$

Hence, friction is directly measured as noted by O'Rourke et al. ${ }^{29}$ Therefore, care should be taken to ensure that the in-cylinder gas pressure acts directly on to the liner's top peripheral rim and not to the holding fixture. If the pressure is applied to the holding fixture, then additional forces would act through the fixture to the load cells and result in erroneous readings. To prevent these spurious in-service readings from the cylinder

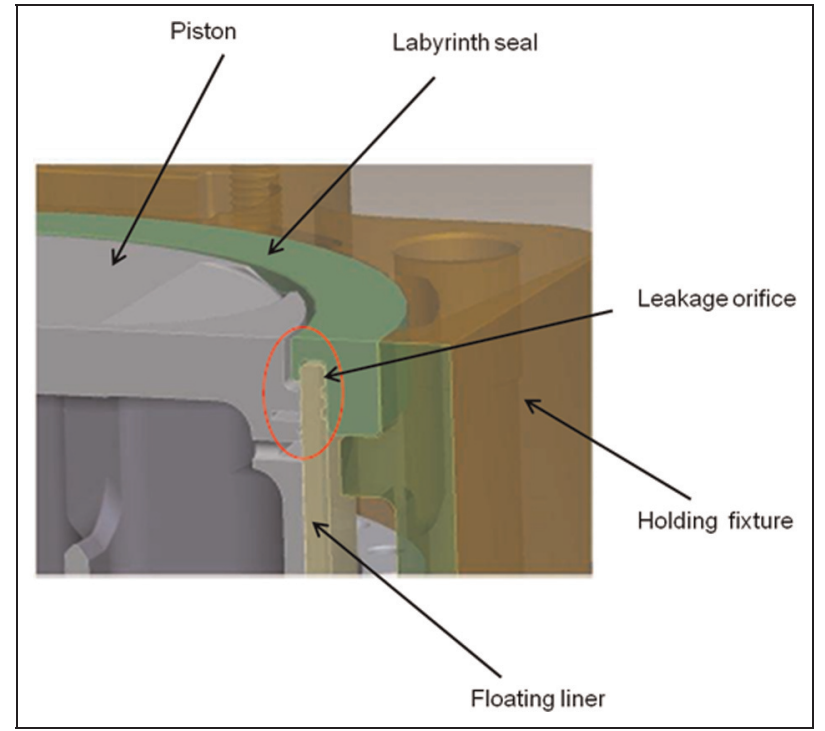

Figure 2. The sealing arrangement at the top of the floating liner.

head clamp loading and unloading due to gas pressure, a labyrinth seal is employed. This allows decoupling of the required seal clamping load from the actual liner, thereby allowing quasi-unconstrained infinitesimal vertical displacements.

Figure 2 shows the top constrained 20MnV6 alloy steel seal ring (vertically constrained), which is an overhanging precision fit over the floating liner of the same material. The internal diameter intrusion of the alloy steel seal ring requires a stepped piston crown as shown in the figure.

Unlike other floating-liner arrangements, where a spring-damper arrangement is used to palliate any shock loading of the liner, the use of a labyrinth seal ensures smooth-running frictionless operation at the liner top rim, but at the expense of some side leakage of gas through the sealing orifice (gap) as shown in the figure. Therefore, a miniature Kistler pressure transducer is inserted through the gap in order to measure the leakage pressure and to apply the correct applied pressure to obtain the liner pressure load as

$$
P=2 \pi r_{\min } b\left(p_{c}-p_{l}\right)
$$

Friction can now be obtained directly from equation (1) as $F=-\left(R-P_{r}\right)+P$ as both $P$ and $R$ are measured.

\section{The engine test-bed}

A Honda CRF450R motocross motorcycle engine was chosen because of its relatively high engine speed $(10,000 \mathrm{r} / \mathrm{min})$, high power $(41 \mathrm{~kW})$ and high torque (50 $\mathrm{N} \mathrm{m}$ ) (bore diameter, $96 \mathrm{~mm}$; stroke, $62.1 \mathrm{~mm}$ ). This choice is representative of the highest-performing, naturally aspirated single-cylinder engine technology (i.e. over $90 \mathrm{~kW} / 1$ and $110 \mathrm{~N} \mathrm{~m} / 1$ ). Its high-speed and 
Table I. Test conditions.

\begin{tabular}{llll}
\hline Parameter (units) & \multicolumn{2}{c}{ Value for the following } \\
\cline { 2 - 4 } & Motorised engine & Fired engine \\
\hline Engine speed (r/min) & 2500 & 2500 & 2500 \\
Throttle position (\%) & 100 & 25 & 33 \\
Chamber pressure (bar) & 19 & 16 & 35 \\
Dynamometer torque $(\mathrm{N}$ m) & $\mathrm{N} / \mathrm{A}$ & 30 & 72 \\
Engine torque $(\mathrm{N}$ m) & $\mathrm{N} / \mathrm{A}$ & 7.5 & 18 \\
Test cell temperature $\left({ }^{\circ} \mathrm{C}\right)$ & 20.8 & 21.6 & 20.2 \\
Test cell pressure $(\mathrm{mbar})$ & 1020 & 1015 & 1006 \\
Test duration $(\mathrm{s})$ & 30 & 20 & 20 \\
Air-to-fuel ratio & $\mathrm{N} / \mathrm{A}$ & $13.5: 1$ & $13.0: 1$ \\
Coolant temperature $\left({ }^{\circ} \mathrm{C}\right)$ & $\mathrm{N} / \mathrm{A}$ & $\mathrm{N} / \mathrm{A}$ & $\mathrm{N} / \mathrm{A}$ \\
Sump oil temperature $\left({ }^{\circ} \mathrm{C}\right)$ & 25 & 25 & 35 \\
Liner temperature $\left({ }^{\circ} \mathrm{C}\right)$ & 38 & 42 & 48 \\
Lubricant & $\mathrm{SAE} \mathrm{I0W40}$ & SAE IOW40 & SAE IOW40 \\
\hline
\end{tabular}

N/A: not available.

high-load characteristics envelops the transient tribological conditions encountered in a very wide range of engines. The engine OEM barrel was replaced by a wet barrel containing the floating liner. For the shortduration testing, typically less than $5 \mathrm{~min}$, natural air cooling was found to suffice. Rubbing thermocouples on the outer surface of the liner and control of the bulk oil temperature ensured testing repeatability. The diameter of the available load cells, the minimum recommended wall thickness of the liner (advised through use of finite element modal analysis ${ }^{27}$ ) and the engine architectural constraints exclude the use of a low-elastic-modulus light-alloy cylinder liner. Furthermore, load cell structural bending limitations and stress concentrations due to the concentrated loads preclude the use of an aluminium alloy. Therefore, low-alloy steel $20 \mathrm{MnV} 6$ is chosen in the construction of the floating liner. This is because of its long successful use in cylinder liner applications when coated with $\mathrm{Ni}-\mathrm{SiC}$ bore coating (Capricorn Automotive Ltd) which is common on both aluminium and steel liners. The piston-steel liner nominal clearance is $100 \mu \mathrm{m}$.

Because of the differential operating temperature, there is a need to control the clearance between the cylinder liner and the housing, and thus to minimise the induced stresses in the OEM aluminium structure. The choice of housing material was restricted to materials with a coefficient of thermal expansion between 16 $\mathrm{ppm} / \mathrm{K}$ and $18 \mathrm{ppm} / \mathrm{K}$, and a yield strength significantly higher than that of the original donor engine barrel. Austenitic stainless steel grade 304 satisfies these criteria, with the added benefit of minimal corrosion in an aqueous environment.

The engine was mounted on to an Oswald $250 \mathrm{~kW}$ transient dynamometer. The assembly incorporates the engine with transmission engaged in second gear with a speed ratio of $4: 1$. All the standard engine testing parameters (the chamber pressure, the air-to-fuel ratio, the test cell humidity, the test cell temperature, the input temperatures of the fuel and the coolant, etc.) were

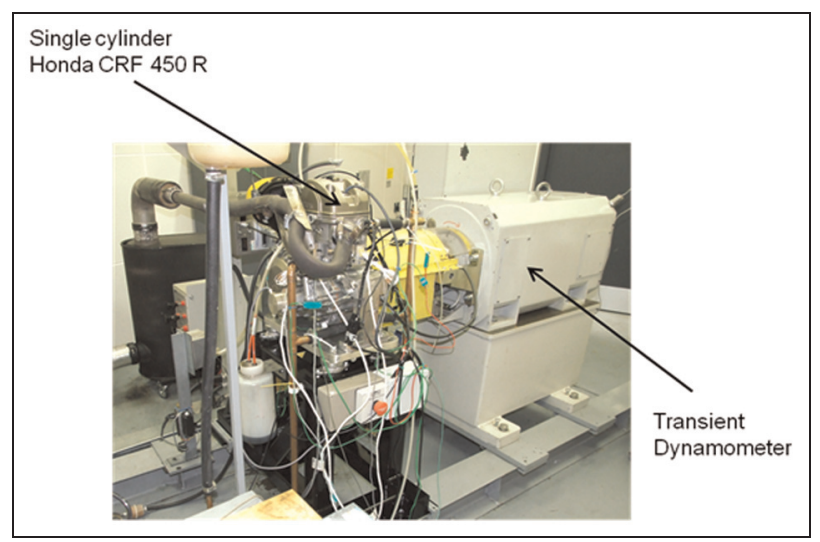

Figure 3. The engine test-bed.

logged as well as friction to ensure the reliability and consistency of the acquired results. Table 1 provides the controlled running conditions for motorised engine conditions as well as fired engine conditions. The basic set-up is shown in Figure 3.

\section{Testing for floating liner operational integrity}

The first step in the testing procedure is to ascertain the operational integrity of the floating-liner system. Referring to equation (1), it is clear that, with the cylinder head removed (Figure 4(c)), there is no significant pressure loading of the liner. Thus, the only applied force to the liner would be friction as the result of its interactions with the piston: $P \approx 0 ;-F=m a_{l}$. Considering the interfacial shear between a film of lubricant and the bounding solid surfaces (those of the piston and the liner), Figure 4(b) shows that the friction acting on the liner and the friction acting on the piston are in the same sense. Thus, the liner is dragged by the moving piston. The liner is restrained by the 


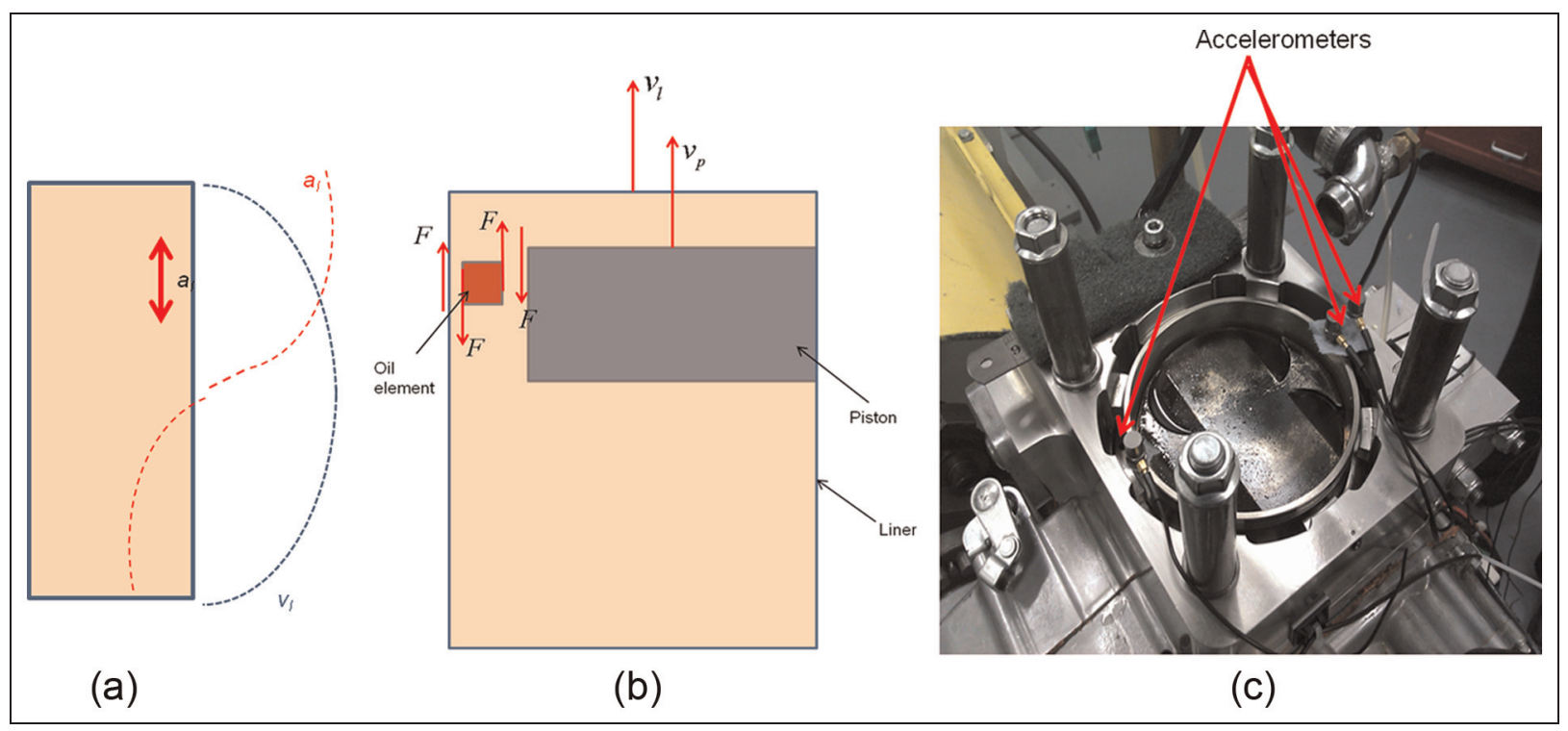

Figure 4. Floating liner with the cylinder head off: (a) liner kinematics; (b) friction generation; (c) measurement of the inertial dynamics.

arrangement of the load cells; hence there is a significant difference between its acceleration $a_{l}$ and the acceleration $a_{p}$ of the piston. Therefore, a film of lubricant is expected to entrain into all the piston-liner conjunctions, which is sheared at the relative sliding velocity $\Delta u=v_{p}-v_{l}$, in the opposite sense to that of the piston motion. As long as this relative motion persists (i.e. $\Delta u \neq 0$ ), the liner velocity remains proportional to the piston speed, which follows a quasi-harmonic (sinusoidal) variation ${ }^{30}$ as in Figure 4(a) according to

$$
v_{p}(\varphi)=r \omega\left[\sin (\omega t)+\frac{r}{2 \ell} \sin (2 \omega t)+\cdots\right]
$$

where $\varphi=\omega t$ is the nominal position of the crank angle (with the TDC; the TDC is designated at the position $\varphi=0^{\circ}$ in transition between the compression and the power stroke and every $720^{\circ}$ thereafter in the fourstroke engine used). $r$ and $\ell$ are the radius of the crank pin and the length of the connecting rod respectively.

The viscous friction is

$$
\begin{aligned}
F & =\tau A \\
& =\left( \pm \frac{h}{2} \frac{\partial p}{\partial x}+\frac{\eta \Delta u}{h}\right) A
\end{aligned}
$$

where the Poiseuille shear (the first term in the parentheses) is insignificant because of the small pressure gradient in the axial direction of the piston with an open cylinder head. Hence, the friction $F \propto \Delta u \propto v_{p}$ (i.e. is proportional to the piston speed) and the motion of the floating liner with the cylinder head off is also quasiharmonic (Figure 4(a)). This is ascertained by positioning accelerometers on the rim of the floating liner as well as the holding fixture, firmly attached to the engine block. This test is crucial in order to ensure that the engine block vibration, which is prevalent in the case of a single-cylinder engine, does not affect the integrity of the load cell readings. Therefore, with the cylinder head removed and friction being the only applied force, a quasi-harmonic load cell output is expected, proportional to $\Delta u$ (or the piston speed $v_{p}$ ). The floating-liner motion may be regarded as semi-simple harmonic. This is verified by the results in Figure 5.

Figure 5 shows the measured friction at the engine speed of $500 \mathrm{r} / \mathrm{min} ; F=-m a_{l}$ for 2 engine cycles with no cylinder head in place. The piston speed (equation (3)) is also plotted in the same figure. Note that except at the dead centre reversals (TDC and bottom dead centre (BDC), every $180^{\circ}$ crank angle position) and in their immediate vicinity, the slope of the friction trace is directly proportional to that of piston speed or the relative sliding velocity $\Delta u$. This suggests that the dominant mechanism underlying friction is through viscous shear of a lubricant film, as already discussed above. This direct proportionality is lost at the dead centre reversals, indicating the presence of some boundary friction. Therefore, a mixed regime of lubrication is prevalent at the TDC and BDC (Figure 5). The friction trace $\left(F=R-P_{r}\right)$ is presented (as is usual in all piston-liner analyses) to show the sense of friction. Therefore, at $90^{\circ}$ crank angle (midstroke) and at intervals of $180^{\circ}$ thereafter, there is a sense of friction reversal. If the sense of friction is ignored, this represents a minimum point with zero slope, following the slope of the piston velocity, which indicates that $\nu_{p} \equiv$ maximum and hence $a_{p}=0$. Therefore, using equation (1), it is clear that $F=-P$ since $m a_{l}=0$. It is also clear that, at these positions, $a_{l}=a_{p}$, indicating that there is no slippage between the liner and the piston surfaces $(F=$ $0)$. Therefore, a change in the sense of friction occurs at the midspan piston position, with $v_{l}=v_{p}$; thus, $\Delta u=0$ and viscous shear diminishes. 


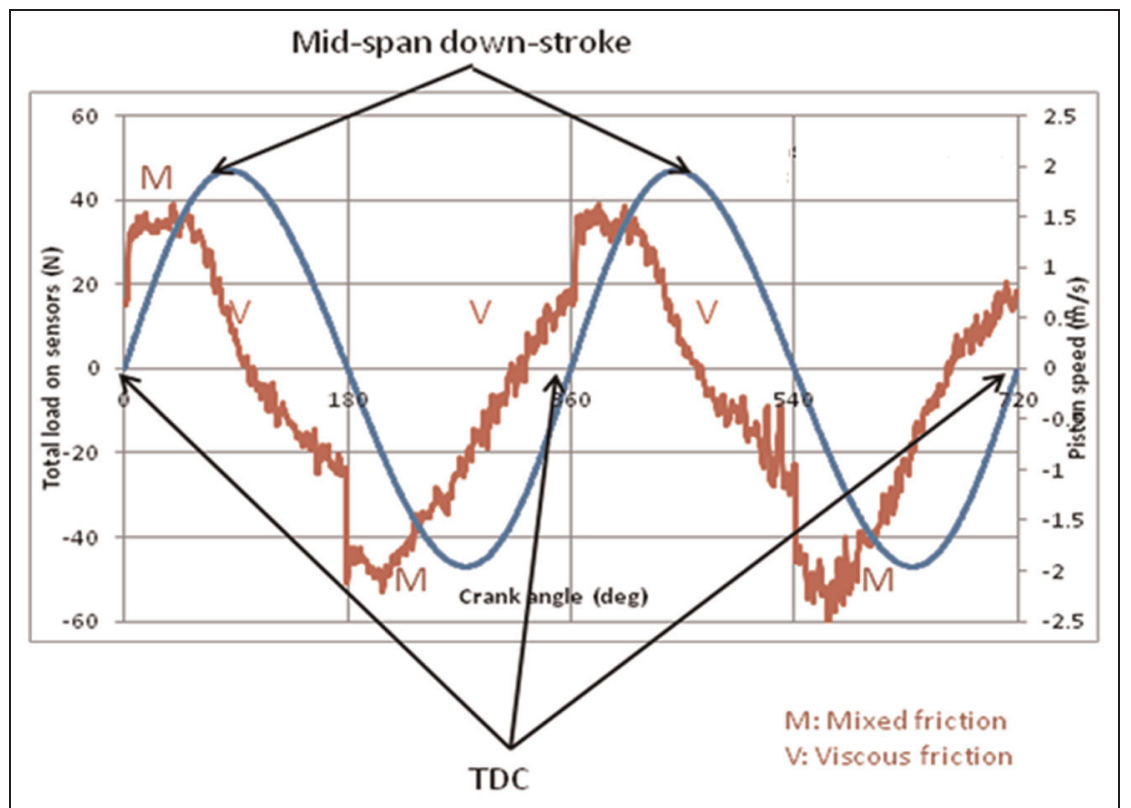

Figure 5. Measured friction with cylinder head removed. TDC: top dead centre.

\section{Engine friction under motorised and fired conditions}

Most reported work with floating liners incorporated in test rigs or engines has been related to motorised engine running conditions or has been undertaken in quite-low-speed fired tests with significant noise and vibration. $^{23,25,26,29}$ However, some improvements have been made to enable measurements under fired conditions, e.g. in the paper by Furuhama and Sasaki. ${ }^{24}$ The motorised tests represent relatively cold running conditions; at low engine speeds, this corresponds to some urban driving conditions which can lead to more significant viscous frictional power loss and increased emissions. These conditions constitute parts of the North American emission cycle tests and the New European Emission Driving Cycle. ${ }^{31}$ These conditions also reduce the large number of interactions that occur under fired engine running conditions, which are initiated by reduced lubricant viscosity (thinner films, and thus increased boundary interactions) and thermoelastic deformation of the liner and the piston skirt, thus reduced the running clearances. ${ }^{20-22}$

Morris et al. ${ }^{6}$ have shown through numerical analysis that thermal mixing at the inlet of the compression ring-liner contact results in a rise in the lubricant temperature above that of both the contiguous solid boundaries as the result of convective heat transfer from the surfaces into the entrant lubricant, and its subsequent shear heating. Therefore, under motorised conditions, with low solid boundary temperatures, the lubricant contact temperature remains only marginally above that in the bulk (the sump temperature). Consequently, the relatively high viscosity of cold lubricant in the motorised tests means that the dominant cyclic friction is due to lubricant viscous action in the presence of any film of lubricant. The other source of lubricant shear is due to the Poiseuille flow at the conjunctional inlet at the TDC reversal, if significant chamber pressure is generated under the motorised condition, which is around 19 bar for the Honda CRF450R engine with the cylinder head in place and motoring at $2500 \mathrm{r} / \mathrm{min}$ (Figure 6). Therefore, unlike other reported test rigs, the effect of realistic pressure loading, particularly on the compression ring conjunction, is included in the current motorised tests.

Figure 7(a) shows the measured friction by the floating liner at $2500 \mathrm{r} / \mathrm{min}$. The TDC position is at $720^{\circ}$ crank angle (in transition from the compression stroke to the power stroke). The maximum chamber pressure of 19 bar occurs at this position and every $720^{\circ}$ crank angle thereafter. Positions at $180^{\circ}$ crank angle and every $360^{\circ}$ thereafter correspond to the reversal at the BDC. Friction changes the sense of application at the motion reversal positions. There are slight differences in the friction characteristics at the BDC from the power stroke to the exhaust stroke and from the intake stroke to the compression stroke. The higher friction in the former transition (i.e. the power stroke to the exhaust stroke) is because of a higher pressure gradient change. As in the case of an open cylinder (i.e. head off), the regions in which the friction trace remains proportional to the service parameter $\eta \Delta u \propto v_{p}$ are due to viscous shear of the lubricant film (second term in equation (4)). These mainly occur in all the strokes between piston reversals and particularly at piston midstrokes (at a crank angle of $90^{\circ}$ and every $180^{\circ}$ thereafter).

With the piston fairly closely conforming to the floating liner, it is possible to remove the two piston 


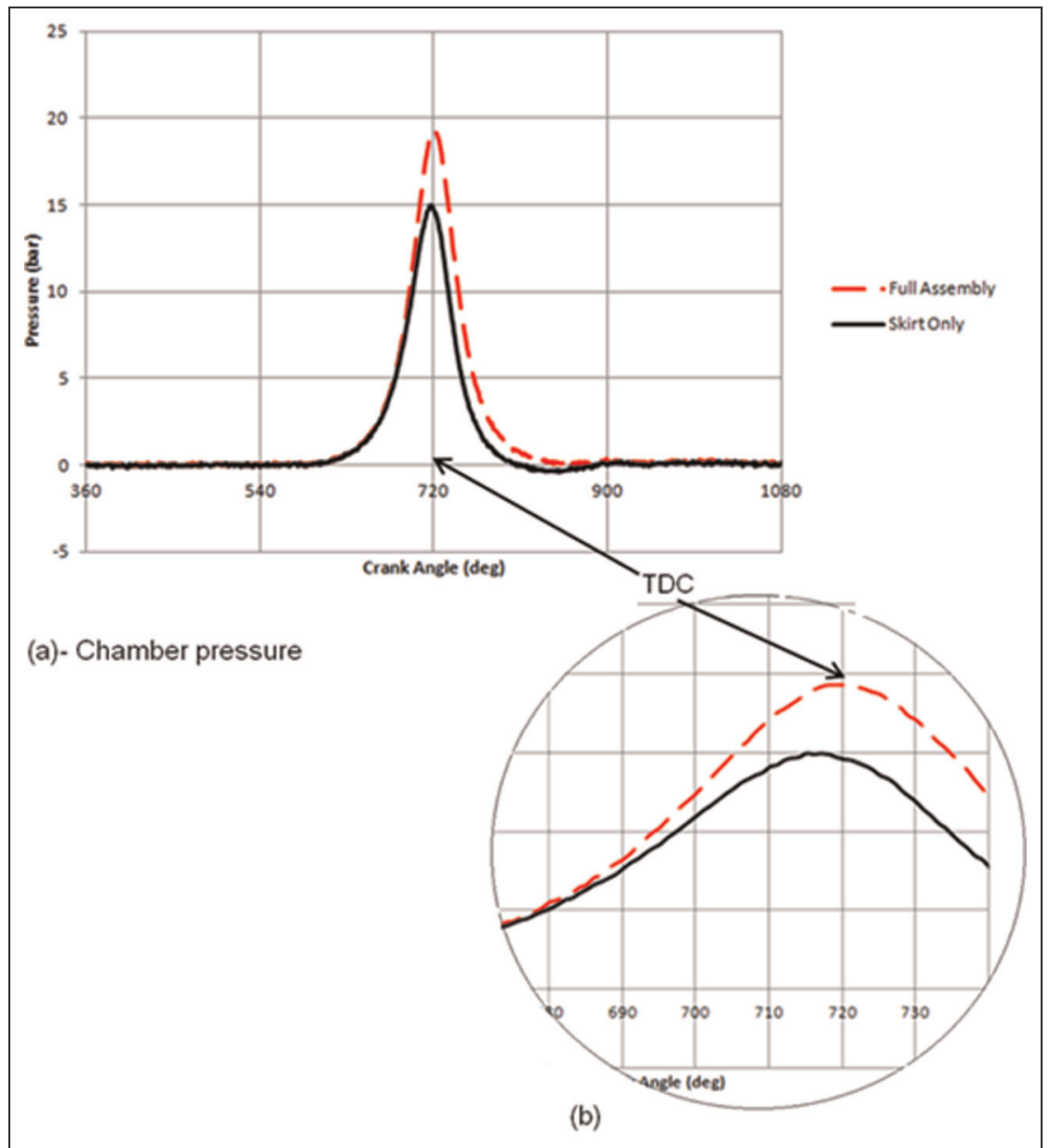

Figure 6. Chamber pressure under the motorised condition at $2500 \mathrm{r} / \mathrm{min}$. TDC: top dead centre.

rings in this configuration (a compression ring and an oil control ring). Figure 7(b) shows the measured friction characteristics with the piston skirt only. Comparison of the result with that of the complete piston assembly (including the rings) shows some interesting features. First, the stipulated friction due to the Poiseuille shear occurs precisely at the BDC reversal from the power to the exhaust stroke (at $180^{\circ}, 90^{\circ}$, etc.) rather than the somewhat delayed peak in Figure 7(a). This is because the compression ring remains at the bottom piston groove land at the BDC reversal which maintains a pressure gradient; this is not present when the ring is removed. The noted difference provides an indication of compression ring action. Namazian and Heywood $^{32}$ showed experimentally that the compression ring remains at the bottom of its groove from the BDC to the midstroke position.

At piston midspan positions, the viscous friction is significantly decreased, because without the oil control ring the skirt-liner conjunction is flooded. Friction in transition from the compression stroke to the power stroke $\left(0^{\circ}\right.$ and $\left.720^{\circ}\right)$ is reduced at the reversal, because of a flooded inlet due to the lack of an oil control ring . Hence, the rise in friction prior to the TDC is entirely due to reduced Poiseuille flow shear loading. With a compression ring present, the peak transition friction occurs closer to the reversal, again as the ring moves this time from the bottom groove land. This is clearly observed in the difference between the measured chamber pressure variation near the TDC for the full piston assembly and that for the skirt only (Figure 6(b)). The sharp rise in friction in the power stroke is due to a combination of Poiseuille shear and somewhat reduced boundary interactions.

An overall comparison of Figure 7(a) and (b) shows that piston-liner friction is mainly governed by the compression ring sealing at the reversals, particularly in the transition from the compression stroke to the power stroke. At the BDC reversals and at the TDC in transition from the exhaust stroke to the intake stroke, the Poiseuille shear is the dominant source of friction, which can be affected by the axial flutter of the compression ring. The delayed nature of Poiseuille friction due to axial motionof the ring is indicative of the crucial sealing role of the compression ring. Another important observation from the motorised test results is that, for most of the engine cycle, lubricant shear (as the result of either Couette flow or Poiseuille flow) accounts for the main contributions, except for the TDC reversal from the compression stroke to the 


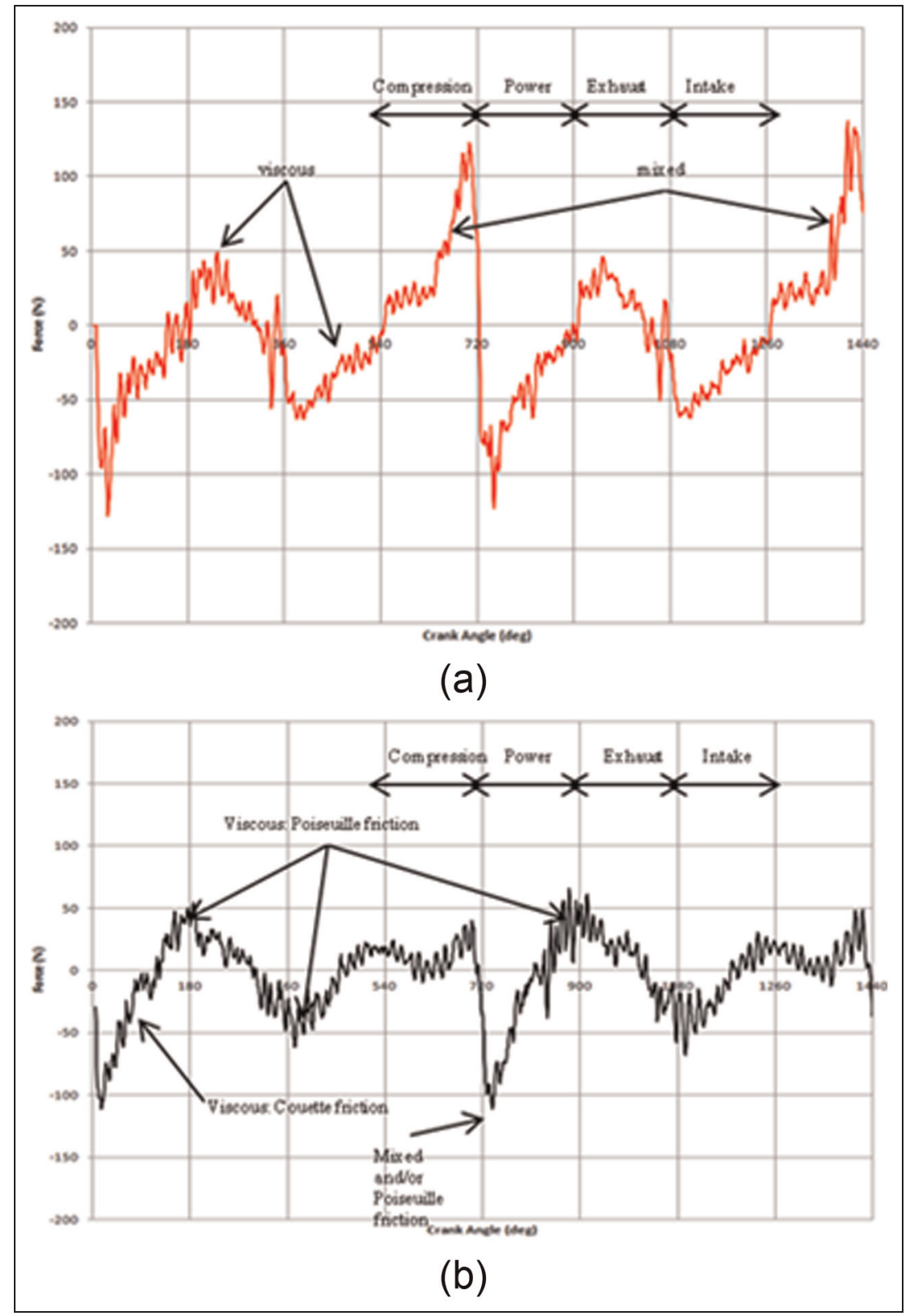

Figure 7. Measured friction under motorised conditions: (a) complete piston assembly; (b) piston skirt conjunction only.

power stroke. However, this may not directly correspond to the fired conditions of a real engine.

The fired engine results, corresponding to steady running conditions at an engine speed of $2500 \mathrm{r} / \mathrm{min}$, a torque of $30 \mathrm{~N} \mathrm{~m}$ at $25 \%$ throttle and a maximum combustion pressure of 16 bar at $13^{\circ}$ past the TDC in the power stroke, are shown in Figure 8.

A comparison of the results in Figure 8 with those in Figure 7(a) shows a number of important changes. First, as would be expected, the contribution to friction due to the viscous shear of the lubricant film is decreased because of the lower effective viscosity (equation (4)) caused by the rising temperatures of contacting bounding solids under fired conditions. Note that the bulk oil temperature at $25^{\circ} \mathrm{C}$ is increased above the liner temperature at the contact inlet and is further increased through shear in transit through the contact. ${ }^{6}$
Thus, the entrant lubricant flows into the contact of all the piston-liner conjunctions at a higher temperature. As the result of short testing times the difference between the liner temperature for motorised conditions and that for fired conditions is only a few degrees Celsius in these cases. However, with longer testing periods a larger difference would be expected. There is a significant reduction in friction at the TDC reversal in the latter stages of compression under fired conditions. This is because of a higher side load (engine torque), and the compression ring sealing function is enhanced. Thus, there is a lower pressure gradient $\mathrm{d} p / \mathrm{d} x$ across the ring as well as a reduced film thickness due to a lower lubricant viscosity, as already noted. Therefore, the influence of Poiseuille shear $(h / 2)(\mathrm{d} p / \mathrm{d} x)$ is significantly decreased in comparison with the motorised results in Figure 7(a). Immediately upon reversal and 


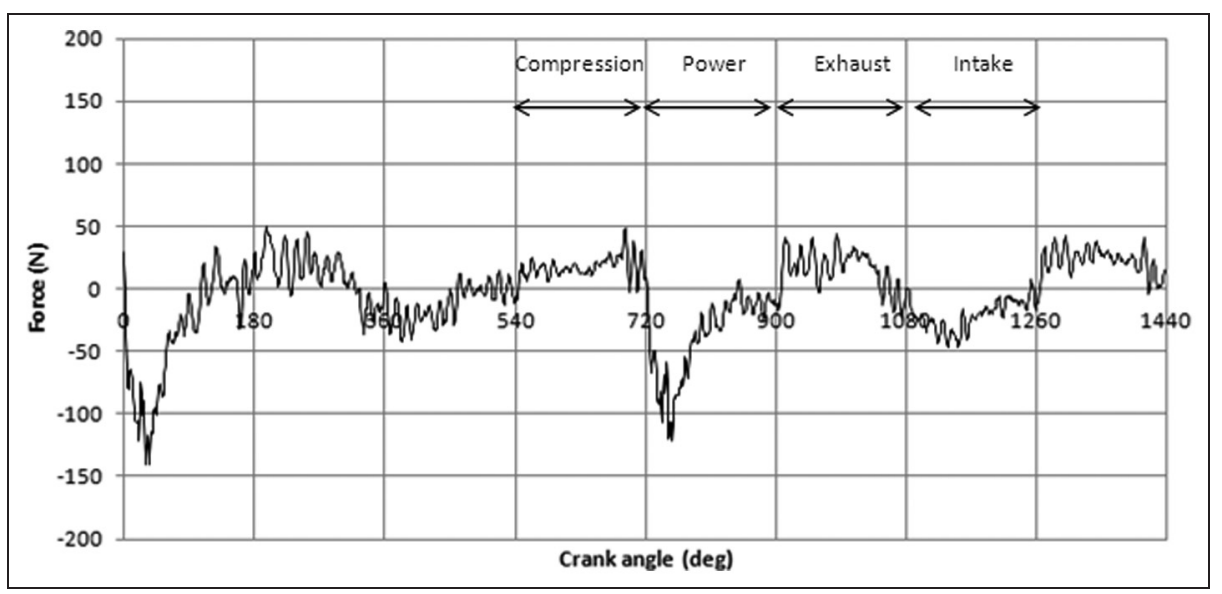

Figure 8. Measured friction under fired engine conditions at an engine speed of $2500 \mathrm{r} / \mathrm{min}$ and a torque of $30 \mathrm{~N} \mathrm{~m}$.

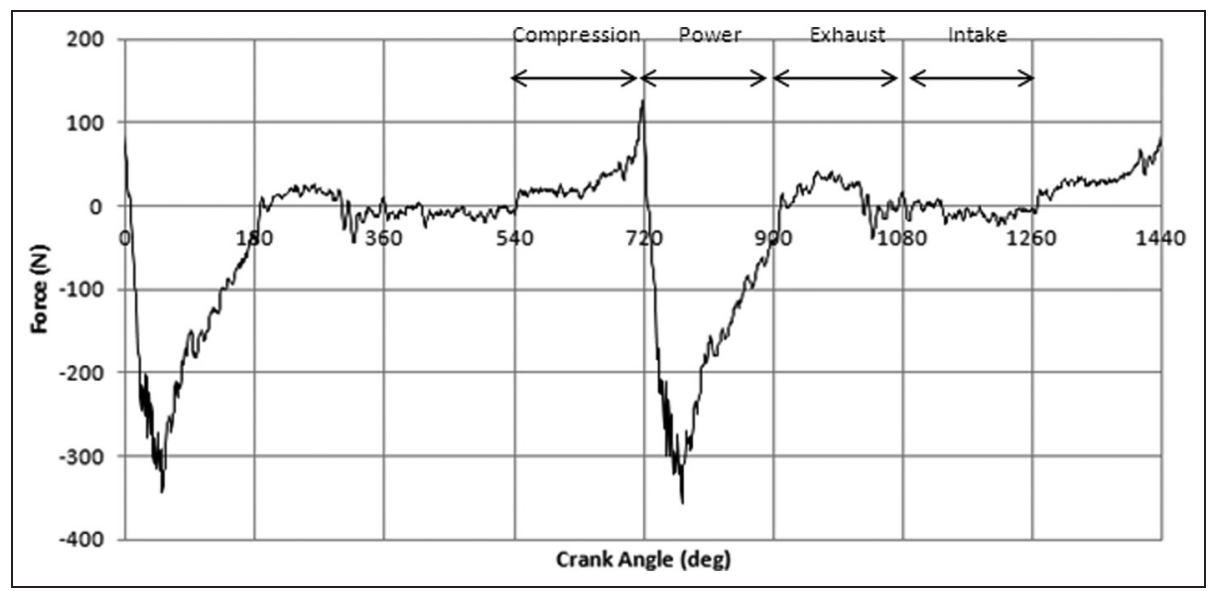

Figure 9. Measured friction under fired conditions at an engine speed of $2500 \mathrm{r} / \mathrm{min}$ and a torque of $72 \mathrm{~N} \mathrm{~m}$.

within the power stroke, however, friction is increased under fired conditions because a thinner lubricant film results in increased boundary interactions.

\section{Conclusions}

The use of an instrumented floating liner has indicated the transient nature of the regime of lubrication in piston-cylinder conjunctions. It is shown that hydrodynamic, mixed and boundary regimes of lubrication are encountered in an engine cycle, the latter two at TDC reversals in transition from the compression stroke to the power stroke. During most of the engine cycle, friction is dominated by the viscous action of the lubricant film as a function of the sliding velocity of the piston, except for the reversals at the TDC (excluding that from the compression stroke to the power stroke) and $\mathrm{BDC}$, where the change in the contact pressure gradient causes significant Poiseuille shear. The design provisions made with the floating liner enables the piston rings to be removed under motorised conditions. The measured data showed that the influence of the compression ring sealing upon friction is pertinent at piston reversal positions and particularly at TDC reversal prior to the power stroke. The ensuing mixed regime of lubrication at this juncture represents a significant portion of cyclic friction. As the engine torque is increased towards $33 \%$ wide-open throttle the dominance of this source of cyclic friction becomes more apparent (Figure 9). Therefore, to reduce piston-cylinder friction, it has been surmised and numerically shown ${ }^{3,15}$ that surface texturing at the TDC reversal would be beneficial. The results of the current investigation support this supposition. A thicker lubricant film would reduce compression ring-cylinder interactions at the TDC from the compression stroke to the power stroke but can also lead to lack of sealing and oil loss. Investigation of this aspect of work, using localised textured liner surfaces with the floating liner constitutes the future direction of the current research. Another important point is the inherent unbalanced nature of single-cylinder geometry, rendering an unbalanced response at a multitude of engine order harmonics. ${ }^{30}$ This results in a certain amount of noise content in the floating-liner dynamics, and thus in the load cell signals, which is more significant at lower engine loadings 
(e.g. Figure 8 when compared with Figure 9). Therefore, some multi-cylinder testing may be beneficial for future work.

\section{Acknowledgements}

The authors acknowledge the technical support of a consortium of industrial concerns whose participation in this work is also acknowledged, particularly in this instance Capricorn Automotive Ltd.

\section{Declaration of conflict of interest}

The authors declare that there is no conflict of interest.

\section{Funding}

This work was financially supported by the Engineering and Physical Sciences Research Council with the Program Grant: Encyclopaedic (grant number: EP/G012334/1), under which the current research is conducted, and a consortium of industrial concerns, including BP Castrol, Aston Martin Lagonda, Capricorn Automotive, Ricardo Consulting Engineers, ProDrive and ES Technology and, in particular, Capricorn Automotive Ltd.

\section{References}

1. Andersson BS. Company's perspective in vehicle tribology. In: 18th Leeds-Lyon Symposium (eds D Dowson, CM Taylor and M Godet), Lyon, France, 3-6 September 1991, pp. 503-506. New York: Elsevier.

2. King J. The King review of low carbon cars. Norwich: The Stationery Office (HMSO), 2007.

3. Gohar R and Rahnejat H. Fundamentals of tribology. London: Imperial College Press, 2008.

4. Bolander NW, Steenwyk BD, Sadeghi F and Gerber GR. Lubrication regime transitions at the piston ringcylinder liner interface. Proc IMechE Part J: J Engineering Tribology 2005; 219(1): 19-31.

5. Mishra PC, Rahnejat $\mathrm{H}$ and King PD. Tribology of the ring-bore conjunction subject to a mixed regime of lubrication. Proc IMechE Part C: J Mechanical Engineering Science 2009; 223(4): 987-998.

6. Morris N, Rahmani R, Rahnejat $\mathrm{H}$ et al. Tribology of piston compression ring conjunction under transient thermal mixed regime of lubrication. Tribol Int 2012; 69: 248-258.

7. Knoll GD and Peeken HJ. Hydrodynamic lubrication of piston skirts. Trans ASME 1982; 104: 504-509.

8. Oh KP, Li CH and Goenka PK. Elastohydrodynamic lubrication of piston skirts. Trans ASME, J Tribol 1987; 109: 356-362.

9. Balakrishnan $\mathrm{S}$ and Rahnejat $\mathrm{H}$. Isothermal transient analysis of piston skirt-to-cylinder wall contacts under combined axial, lateral and tilting motions. $J$ Phys $D$ : Appl Phys 2005; 38(5): 787-799.

10. Baker CE, Theodossiades $\mathrm{S}$, Rahnejat $\mathrm{H}$ and Fitzsimons B. Influence of in-plane dynamics of thin compression rings on friction in internal combustion engines. Trans ASME, J Engng Gas Turbines Power 2012; 132(9): 092801-1-092801-11.
11. Akalin $\mathrm{O}$ and Newaz GM. Piston ring-cylinder bore friction modeling in mixed lubrication regime, Part I analytical results. Trans ASME, J Tribol 2001; 123: 211-218.

12. Ma M-T, Sherrington I and Smith EH. Analysis of lubrication and friction for a complete piston-ring pack with an improved oil availability model - Part 1: circumferentially uniform film. Proc IMechE Part J: J Engineering Tribology 1997; 211(1): 1-15.

13. Rahnejat, H., Balakrishnan, S., King, P.D. and HowellSmith, S., In-cylinder friction reduction using a surface finish optimization technique, Proc. IMechE, Part D: J. Automobile Engineering, 2006; 220: 1309-1318.

14. Spencer A, Almqvist A and Larsson R. A semideterministic texture-roughness model of the piston ringcylinder liner contact. Proc IMechE Part J: J Engineering Tribology 2011; 225(6): 325-333.

15. Balakrishnan $\mathrm{S}$, Howell-Smith $\mathrm{S}$ and Rahnejat H. Investigation of reciprocating conformal contact of piston skirtto-surface modified cylinder liner in high performance engines. Proc IMechE Part C: J Mechanical Engineering Science 2005; 219(11): 1235-1247.

16. Piao $Y$ and Gulwadi S. Numerical investigation of the effects of axial cylinder bore profiles on piston ring radial dynamics. Trans ASME, J Engng Gas Turbines Power 2003; 125: 1081-1089.

17. Rahmani R, Theodossiades S, Rahnejat H and Fitzsimons B. Transient elastohydrodynamic lubrication of rough new or worn piston compression ring conjunction with an out-of-round cylinder bore. Proc IMechE Part J: J Engineering Tribology 2011; 226(4): 284-305.

18. Priest M, Dowson D and Taylor CM. Predictive wear modelling of lubricated piston rings in a diesel engine. Wear 1999; 231(1): 89-101.

19. Morris N, Rahmani R, Rahnejat $\mathrm{H}$ et al. The influence of piston ring geometry and topography on friction. Proc IMechE Part J: J Engineering Tribology 2013; 227(2): 141-153.

20. Littlefair B, Howell-Smith S, Theodossiades S et al. Tribology of piston skirt conjunction. In: 3rd European conference on tribology, Vienna, Austria, 7-9 June 2011, 7 pp. Vienna: Österreichische Tribologische Gesellschaft.

21. McClure F. Numerical modelling of piston secondary motion and skirt lubrication in internal combustion engines. $\mathrm{PhD}$ Thesis, Massachusetts Institute of Technology, Cambridge, Massachusetts, USA, 2007.

22. Bai D. Modeling piston skirt lubrication in internal combustion engines. PhD Thesis, Massachusetts Institute of Technology, Cambridge, Massachusetts, USA, 2012.

23. Akalin O and Newaz GM. Piston ring-cylinder bore friction modeling in mixed lubrication regime: Part II - correlation with bench test data. Trans ASME, J Tribol 2001; 123(1): 219-223.

24. Furuhama $\mathrm{S}$ and Sasaki S. New device for the measurement of piston frictional forces in small engines. SAE paper 831284, 1983.

25. Furuhama $\mathrm{S}$ and Takiguchi M. Measurement of piston friction force in actual operating diesel engine. SAE paper 790855, 1980.

26. Yoshida H, Kusama K and Sagawa J. Effects of surface treatments on piston ring friction force and wear. SAE paper 90058, 1990.

27. Gore M, Howell-Smith S, King PD and Rahnejat H. Measurement of in-cylinder friction using the floating 
liner principle. In: ASME 2012 Internal Combustion Engine Division spring technical conference, Turin, Italy, 6-9 May 2012, paper ICES2012-81028. New York: $A S M E$.

28. Littlefair B, De la Cruz M, Mills R et al Lubrication of a flexible piston skirt conjunction subjected to thermoelastic deformation: a combined numerical and experimental investigation. Proc IMechE Part J: J Engineering Tribology, 2013; DOI: doi: 10.1177/1350650113499555.

29. O'Rourke B, Radford D and Stanglmaier R. Tri-axial force measurements on the cylinder of a motorised SI engine operated on lubricants of differing viscosity. Trans ASME, J Engng Gas Turbines Power 2010; 132(9): 092807-1-092807-7.

30. Rahnejat H. Multi-body dynamics: vehicles, machines and mechanisms. Warrendale, Pennsylvania: SAE International, 1998. Bury St Edmunds: Professional Engineering Publishing Limited, 1998.

31. European Federation for Transport and Environment. WHO adds pressure for stricter Euro-5 Standards. T\&E Bulletin 146, European Federation for Transport and Environment, Brussels, Belgium, March 2006.

32. Namazian M and Heywood JB. Flow in piston-cylinderring crevices of a spark-ignition engine: effect on hydrocarbon emissions, efficiency and power. $S A E$ paper $820088,1982$.

\section{Appendix I}

\section{Notation}

$a_{l}$

$a_{p}$

A

$b$ acceleration of the floating liner

acceleration of the piston

conjunctional contact area

width of labyrinth seal rim force

friction

thickness of the lubricant film

length of the connecting rod

mass of the floating liner

hydrodynamic contact pressure

measured pressure in the combustion

chamber

measured leakage pressure from the

labyrinth seal

applied gas force on the upper rim of the floating liner

initial preload value for fitted load cells

radius of the crank pin mean radius of the labyrinth seal instantaneous load cell reading

time

velocity of the floating liner

velocity of the piston

direction of sliding

relative interfacial sliding velocity

dynamic viscosity of the lubricant

viscous shear stress

crank angle

angular velocity of the crankshaft

\section{Abbreviations}

BDC bottom dead centre

TDC top dead centre 